\title{
ACCELERATED FIELD DURABILITY ASSESSMENT OF TWO NON- DURABLE TIMBERS (Ceiba pentandra (L.) Gaertn. and Celtis milbraedii Engl.) IMPREGNATED WITH NATURAL AND INORGANIC PRE- SERVATIVES
}

\author{
C. Antwi-Boasiako and A. H. Baidoo \\ Department of Wood Science \& Technology, Faculty of Renewable Natural Resources \\ Kwame Nkrumah University of Science \& Technology \\ Kumasi-Ghana
}

\begin{abstract}
Some timbers have natural resistance against decay. Others are made durable through treatment with preservatives several of which are noxious (e.g. CCA), destroy delicate body organs and are banned in many countries. Eco-friendly but efficient alternatives from organic sources including heartwood extracts of naturally durable plants are being sought. This study compares the effectiveness of extracts from two durable timbers (i.e. Tectona grandis L. $f$. (teak) and Erythrophleum suaveolens (Guill. \& Perr.) Brenan (potrodom) with three notable inorganic preservatives (i.e. CCA, Pyrinex 48EC and Creosote) on the field performance of two non-durable timbers (i.e. Ceiba pentandra (L.) Gaertn. and Celtis milbraedii Engl.). Mini-stakes (20x2x1 cm) were impregnated [at 1.2 bars, $123^{\circ} \mathrm{C}$ for $3 \mathrm{hrs}$ ] with $0.5 \%$ water-soluble bark extracts of T. grandis and E. suaveolens, CCA (0.5\%), Pyrinex $48 E C$ (0.5\%) and creosote (at manufacturer's specification), and their retention in each stake determined. The stakes were then buried in the topsoil for 20 weeks. Preservative retention is less for the more viscous creosote than its water-borne counterparts. For all the durability parameters studied (i.e. visual ratings, hardness and mass losses), no significant differences $(p<0.05)$ exist between stakes treated with $E$. suaveolens bark extract and CCA (which performed best), as well as between those treated with teak bark extract, creosote and Pyrinex 48EC. Organic preservatives could be promising replacements for several of the harmful conventional types, as the influence of the plant extracts currently studied has proven significant in conferring durability.
\end{abstract}

Keywords: Bio-deterioration, mini-stake, Pyrinex 48EC, service-life, water-soluble extract.

\section{INTRODUCTION}

Wood is one of the indispensable materials of preference for construction. For use in ground contact, several members (especially those from desirable but non-durable timbers) are impregnated with chemicals (termed preserva- tives), which make them less susceptible to attack from bio-degraders including decayfungi, bacteria, termites and marine-borers (Negi, 2004). Besides, preservatives improve fire-resistance of wood in-service (Green et al., 1999; Williams and Feist, 1999). According to 
(Anon., 2005), properly preservative-treated wood can have over 5 to 10 times the servicelife of untreated wood. This life extension saves the equivalent of $12.5 \%$ of Canada's annual log harvest. Factory-treated woods are employed for railroad ties, utility poles, marine piles, decks, fences and other outdoor applications.

Various chemical types for treatment are available for use depending on the attributes required in the particular application and the level of protection needed. Conventional preservatives are of three main classes: Oil-based type (e.g. tar oils and creosote), Organic Solvent type (e.g. benzene hexachloride [BHC] and synthetic pyrethroides) and the Water-soluble type, which comprises leaching types (e.g. zinc chloride, boric acid and borax) and fixed or non -leaching types (e.g. Copper-Chrome-Arsenic composition [CCA], Ammoniacal Copper Zinc Arsenate [ACZA] and Ammoniacal Copper Quaternary compound [ACQ]). Many others are being developed such as Pyrinex 48EC, while banned noxious types include Lindane, Dieldrin, Dichloro-Diphenyl-Trichloroethane (DDT) (FAO, 1991). While a number of the inorganic types (e.g. CCA) have unique adverse effects on organisms on contact by causing tumour and damage to essential body organs (Findlay, 1985), leaching into the ecosystem (Anon., 2009) as well as joining food chains, durability could be imparted by natural chemicals contained in the heartwood extractives of very durable wood species, which are often referred to as extracts (Al-Jeboury et al., 1971; Iinuma et al., 1994; Ejechi, 2004). However, scanty information exists for the efficacy of extracts from tropical timbers in conferring durability, while CCA and other deadly inorganic preservative impregnated wood continue to be the commonest treated lumber worldwide amid much apprehension, as they pose health and ecological problems. As would be expected, the use of CCA is discontinued in the U.S. and Japan (Goktas et al., 2007).

This work, as a follow-up of the preliminary investigation undertaken by Baidoo et al. (2009), compares the effectiveness of the bark extracts of Tectona grandis L.f. and Erythro- phleum suaveolens (Guill. \& Perr.) Brenan (i.e. from organic source) and three extensively used conventional inorganic preservatives from different classes: Creosote [oil type] (Anon., 2009) and two water-borne types: Pyrinex 48EC [an agricultural insecticide formulation also effective against wood termites (http:// www.uapca/product/document/pyrinex)] and CCA [which has a wide spectrum of attack] (Richardson, 1978) on the durability of ministakes of two non-durable timbers (i.e. Ceiba pentandra (L.) Gaertn. and Celtis milbraedii Engl.) in the field. The present investigation and several other on-going screenings seek to contribute to acquiring and facilitating the extensive approval of organic preservatives, which would be easy to use, target-specific, eco -friendly and much valuable to the wood treatment industry and efficiently substitute the traditional preservatives

\section{MATERIALS AND METHODS}

Preparation of stakes, extracts and inorganic preservatives for impregnation of stakes

Ceiba and celtis beams from their stem bases $(70 \mathrm{~cm}$ from diameter at breast height) were airdried to $12-14 \%$ moisture content (mc). Ministakes $(20 \times 2 \times 1 \mathrm{~cm})$ were prepared from their stems ( $8 \mathrm{~cm}$ beneath the bark) and their masses determined. T. grandis and E. suaveolens barks were air-dried to $12-14 \%$ and milled individually to particle size $40-60$ mesh. Their extracts were removed using hot water extraction method (at $70^{\circ} \mathrm{C}$ for 12 hours). Five series of $250 \mathrm{~g}$ of $T$. grandis or E. suaveolens powdered bark were extracted in equal volumes of distilled water $(2050 \mathrm{ml})$. Extracts were stored in a cold room for $24 \mathrm{hrs,}$ then decanted, sieved $(1 \mathrm{~mm}$ mesh) and centrifuged $(1000 \mathrm{xg})$ for 30 mins. The mass of dry extract from the supernatant aliquot $(10 \mathrm{ml})$ each taken from $T$. grandis or E. suaveolens bark water extract $(1000 \mathrm{ml})$ was determined. The average mass of three separate dried extracts was used to determine the concentration $(\mathrm{g} / \mathrm{ml})$ [i.e. in $10 \mathrm{ml}$ of the total $1000 \mathrm{ml}$ of each extract]. From these, $0.5 \%$ concentration of each of the bark extracts was prepared. Similarly, $0.5 \% \quad \mathrm{CCA}$ and 
Pyrinex 48EC were prepared, while creosote was employed at manufacturer's specification. Each charge comprised 15 replicates, which were pressure-impregnated using the Full Cell process (at $123^{\circ} \mathrm{C}$ and 1.2bars for $3 \mathrm{hrs}$ ). Treated stakes were conditioned (at $65 \%$ rh and $25^{\circ} \mathrm{C}$ ) to enhance proper extract fixation. After re-weighing, extract retention was determined from the mass of each extract absorbed as well as the volume of stakes before and after impregnation. Initial weights were then taken for the treated stakes (at 12-14\% mc), while hardness of stakes (based on the depth of penetration of the Pilodyn [Proceq 6J Forest] where $0 \mathrm{~mm}=$ no penetration/greatest hardness: $40 \mathrm{~mm}$ $=$ the deepest penetration/lowest hardness (Brunner and Grüsser, 2006)) was also taken. Untreated stakes for the two timbers served as controls.

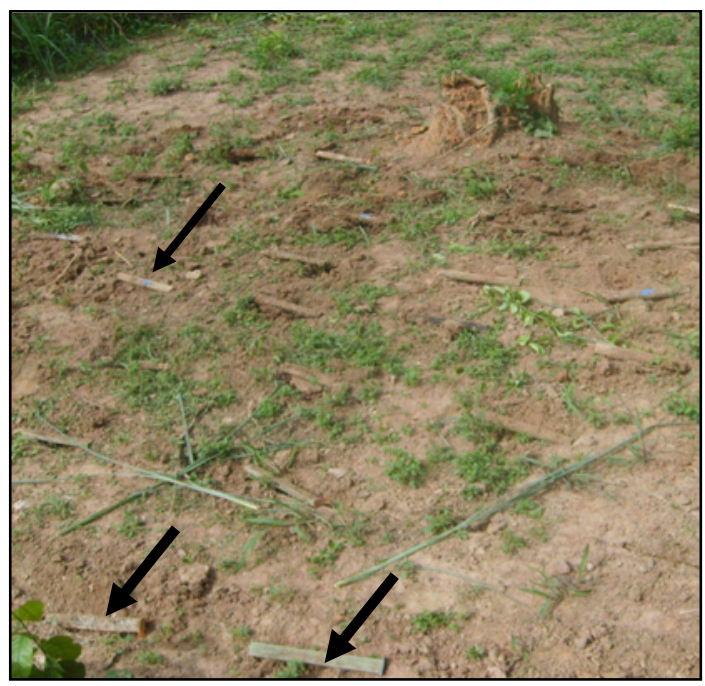

Plate 1: Test field showing stakes buried in the top soil for Accelerated Durability Test

\section{Field test}

Mini-stakes (treated and untreated) were randomly buried $50 \mathrm{~cm}$ apart for 20 weeks in the top soil on a $10 \times 8 \mathrm{~m}$ (Plate 1). Stakes were exhumed and cleaned of all debris. Durabilities of the mini-stakes were rated visually on a scale of 0 to 4 based on EN 252 (Anon., 1989) [0= no termite attack, $1=$ slight attack, $2=$ moderate attack, $3=$ severe attack and $4=$ failure]. They were air-dried to $12-14 \% \mathrm{mc}$ and the hardness of each taken. Their final oven-dry masses (at $103 \pm 2^{\circ} \mathrm{C}$ ) were also determined. Percentage mass loss of each stake $(M)$ was also calculated based on its corrected oven-dry mass using the formula:

$M(\%)=\left(\frac{I-R}{I}\right) \times 100$

\section{RESULTS}

\section{Retention of preservatives in stakes}

Significant differences $(p<0.05)$ exist in the mean retention between the various preservatives used to treat stakes from both ceiba and celtis (Table 1). Generally, Fig. 1 shows that retention was higher in ceiba stakes than for those of celtis. Pyrinex 48EC was retained most, and creosote least in ceiba. However, for celtis, retention was greatest for stakes treated with E. suaveolens (potrodom) and T. grandis (teak) bark water-soluble extracts, while creosote was again retained least. In all, the waterborne preservatives (i.e. Pyrinex 48EC, CCA and bark extracts from the two timbers) could be absorbed and retained greater than the oiltype (i.e. creosote).

Table 1: ANOVA for the retention of preservatives in ceiba and celtis stakes

\begin{tabular}{lccccc}
\hline Source & Degree of Freedom & Sum of Squares & Mean Square & F-Value* & Pr $>$ F \\
\hline Error & 14 & 0.30 & 0.02 & 2.10 & $<0.00017$ \\
Corrected & 135 & 1.19 & 0.01 & & \\
Total & 149 & 1.49 & & & \\
\hline
\end{tabular}

*Significant difference at $p<0.05$.

Journal of Science and Technology ㄷNUST April 2010 


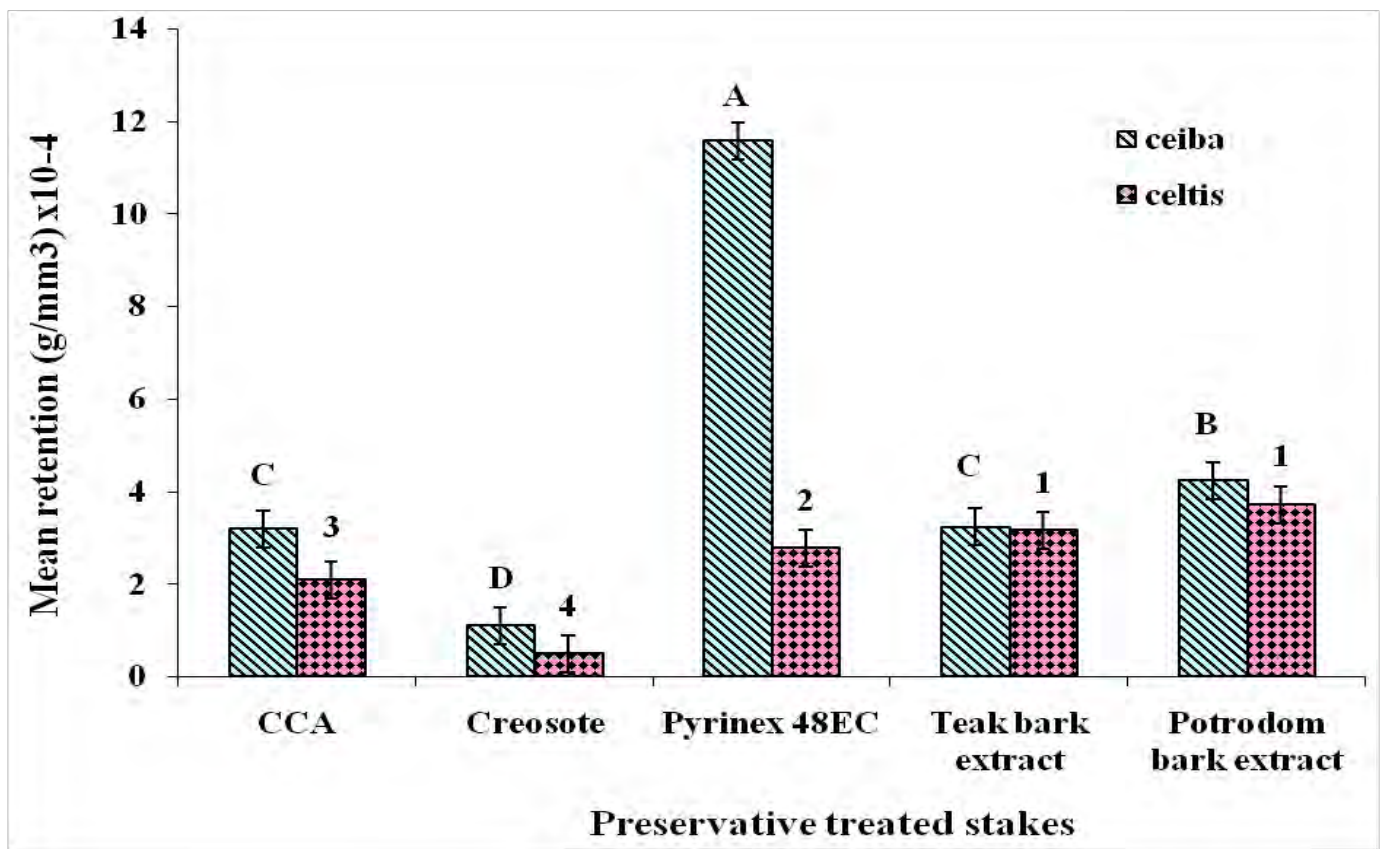

Bars $=$ standard errors. Bars with same letters or figures are not significantly different $(p<0.05)$.

Fig. 1: Preservative retention in $C$. pentandra (ceiba) and $C$. milbraedii (celtis) stakes

Durability Assessment of ceiba and celtis stakes after field exposure

Results for the resistance of ceiba and celtis stakes against wood-destroying organisms, determined after field exposure using visual durability rating, hardness and mass losses, are presented below:

\section{Visual durability ratings for stakes}

The visual durability ratings for treated and untreated stakes for the two timbers show significant difference $(\mathrm{p}<0.05)$ between their treatment means (Table 2). Controls (especially those of ceiba) recorded the highest ratings compared with the natural and inorganic preservative-treated stakes (Fig. 2). This was followed by those treated with creosote and Pyrinex 48EC. No significant differences $(\mathrm{p}<0.05)$ exist between ceiba and celtis stakes treated with CCA, teak and E. suaveolens bark extracts, which showed the least signs of attack by bio-degraders and discolourations by stains. Stakes showing various forms of deterioration after burial in the field are presented in Plates 2 -5 .

Table 2: ANOVA for percentage visual durability ratings for treated and untreated ceiba and celtis stakes

\begin{tabular}{lcccccc}
\hline Source & $\begin{array}{l}\text { Degree of } \\
\text { Freedom }\end{array}$ & Sum of Squares & \multicolumn{2}{c}{ Mean Square } & F-Value* & Pr $>$ F \\
\hline Error & 14 & 245.13 & 12.91 & 0.19 & 67.31 & $<0.0001$ \\
Corrected & 135 & 30.67 & & & & \\
Total & 149 & 275.80 & & & & \\
\hline
\end{tabular}

*Significant difference at $p<0.05$ 


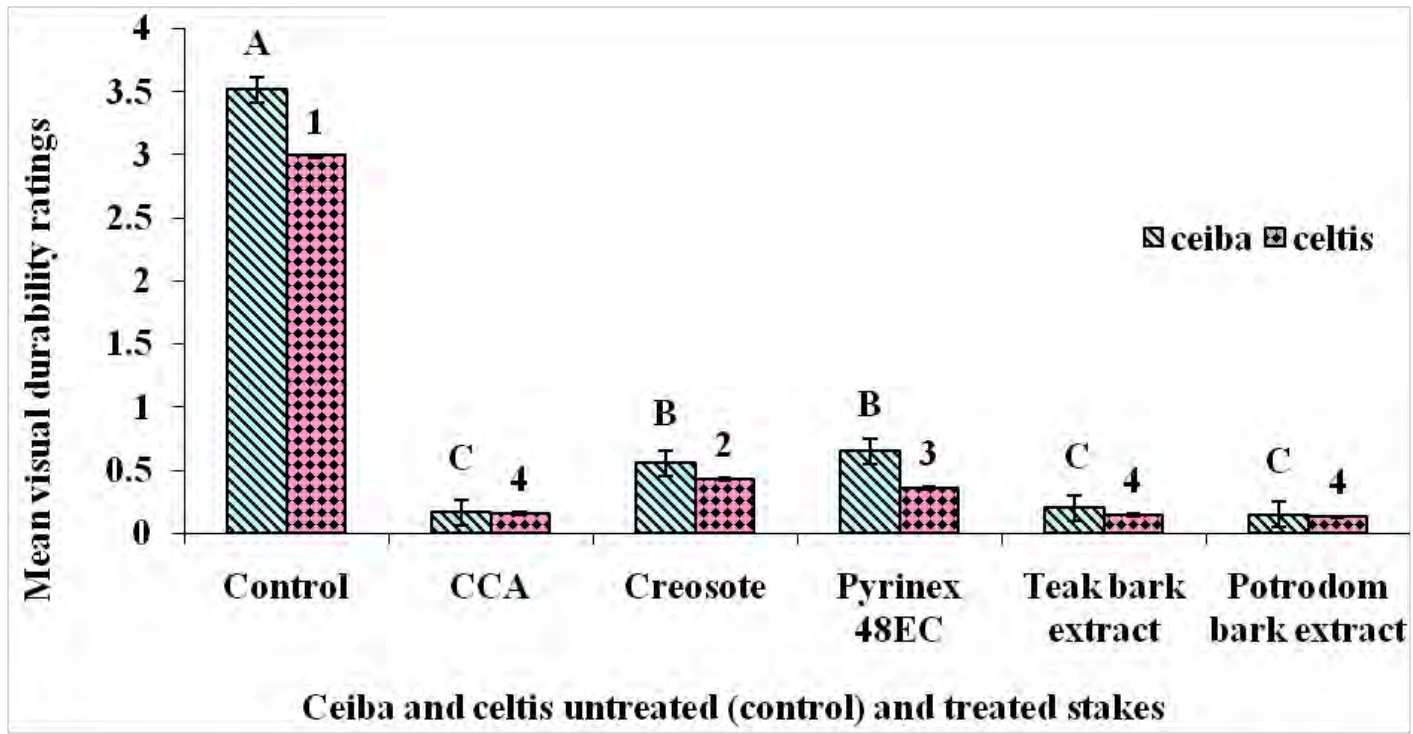

Bars $=$ standard errors. Bars with same letters or figures are not significantly different $(p<0.05)$

Fig. 2: Visual durability ratings for untreated (control) and treated $C$. pentandra (ceiba) and $C$. milbraedii (celtis) stakes

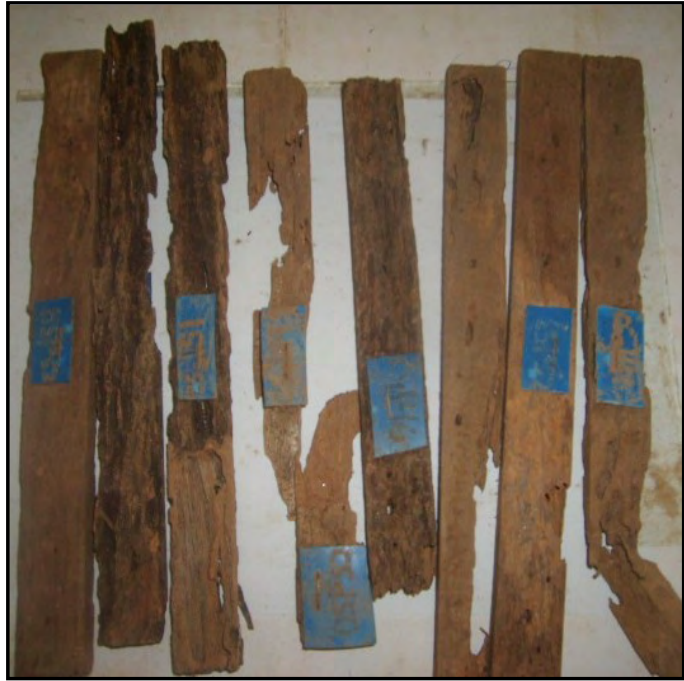

Plates 2a: Ceiba untreated (i.e. control) stakes after 20-week field exposure showing signs of damage

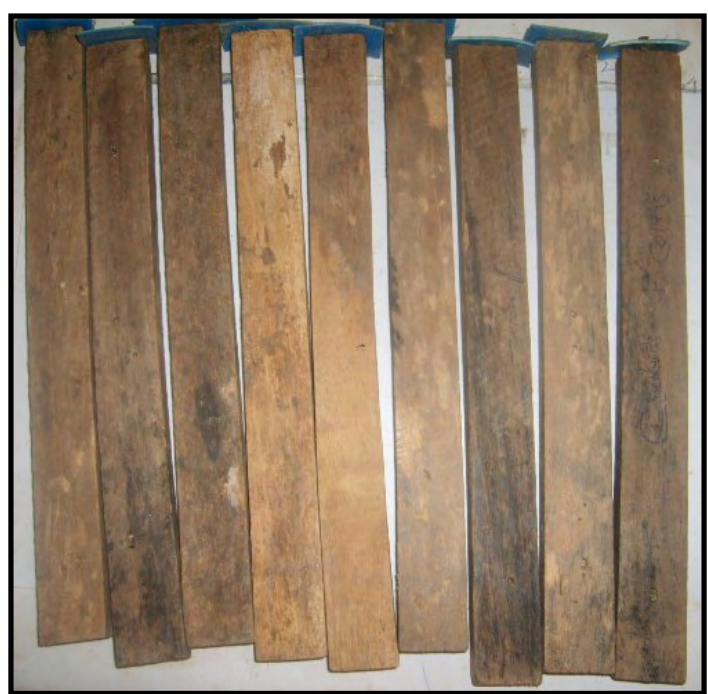

Plate 2b: Celtis control (untreated stakes) after 20-week field exposure showing some signs of damage including discolouration. 


\section{Hardness losses for stakes}

Significant difference $(\mathrm{p}<0.05)$ exists in hardness loss for all the stakes (Table 3). Controls of the two timbers again recorded the highest loss in hardness; they were the softest after field exposure. Stakes treated with $E$. suaveolens bark extracts recorded the least mean hardness loss, then those with CCA followed by creosote and Pyrinex 48EC, and the least with teak bark extract. The trend is the same for both wood species (Fig. 3).

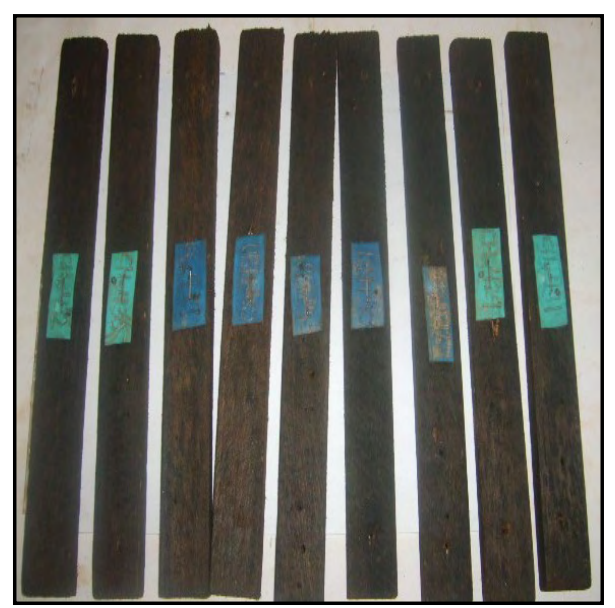

Plate 3a: CCA-treated ceiba stakes after 20week field exposure

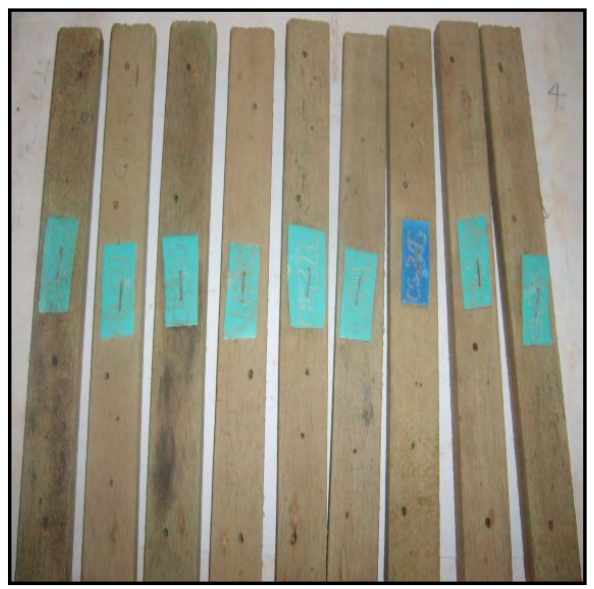

Plate 4a: Creosote-treated ceiba stakes after 20-week field exposure

\section{Mass losses for stakes}

ANOVA (Table 4) shows significant difference $(p<0.05)$ in percentage mass loss between all the mini-stakes (treated and untreated) of the two timbers. Fig. 4 shows that ceiba and celtis controls recorded the highest percent mass losses (particularly those of ceiba), while $E$. suaveolens bark extract and CCA treated stakes recorded the least biomass degradation and performed best in the field. For the treated stakes, those impregnated with teak extract comparatively performed the poorest.

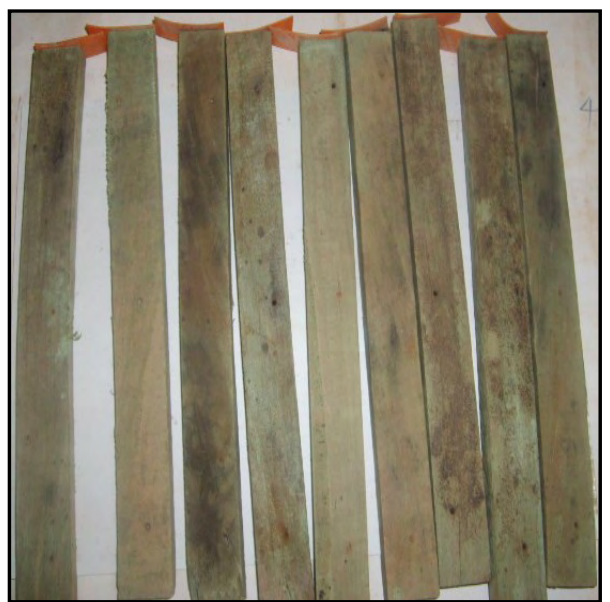

Plate 3b: CCA-treated celtis stakes after 20week field exposure

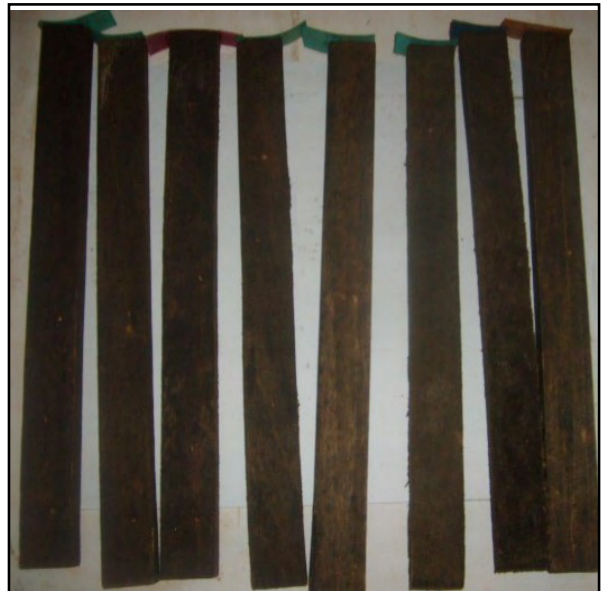

Plate 4b: Creosote-treated celtis stakes after 20-week field exposure 
24 Antwi-Boasiako and Baidoo

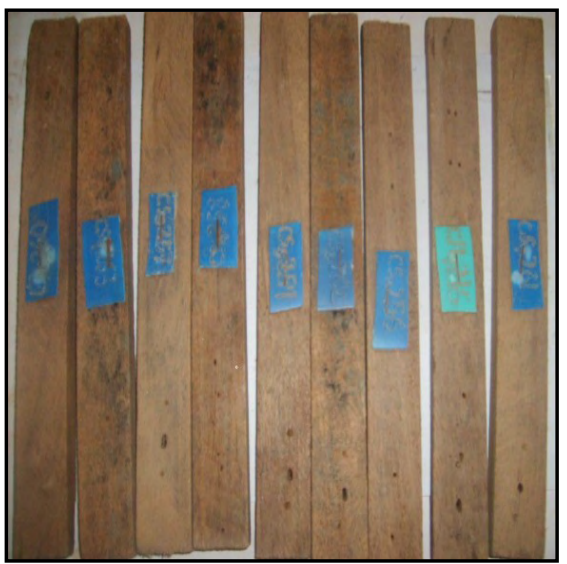

Plate 5a: Pyrinex 48EC-treated ceiba stakes after 20-week field exposure

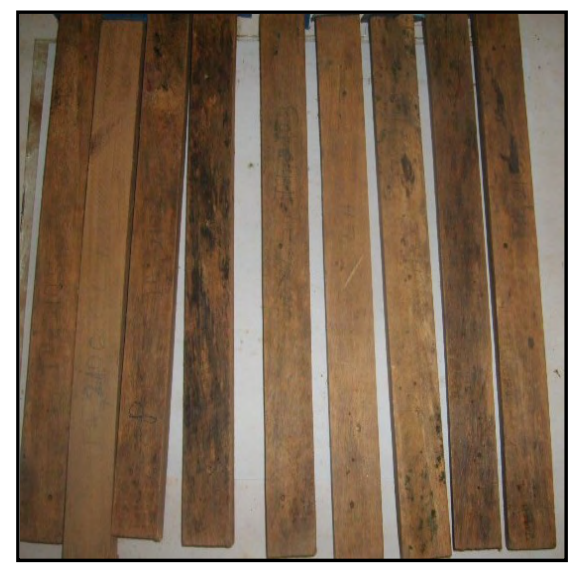

Plate 5b: Pyrinex 48EC-treated celtis stakes after 20-week field exposure

Table 3: ANOVA for percentage hardness loss for treated and untreated ceiba and celtis stakes

\begin{tabular}{lccccc}
\hline Source & Degree of Freedom & Sum of Squares & Mean Square & F-Value* & Pr $>$ F \\
\hline Error & 14 & 182081.33 & 9583.23 & 4.78 & $<0.0001$ \\
Corrected & 135 & 321112.53 & 2006.95 & & \\
Total & 149 & 503193.86 & & & \\
\hline
\end{tabular}

*Significant difference at $p<0.05$.

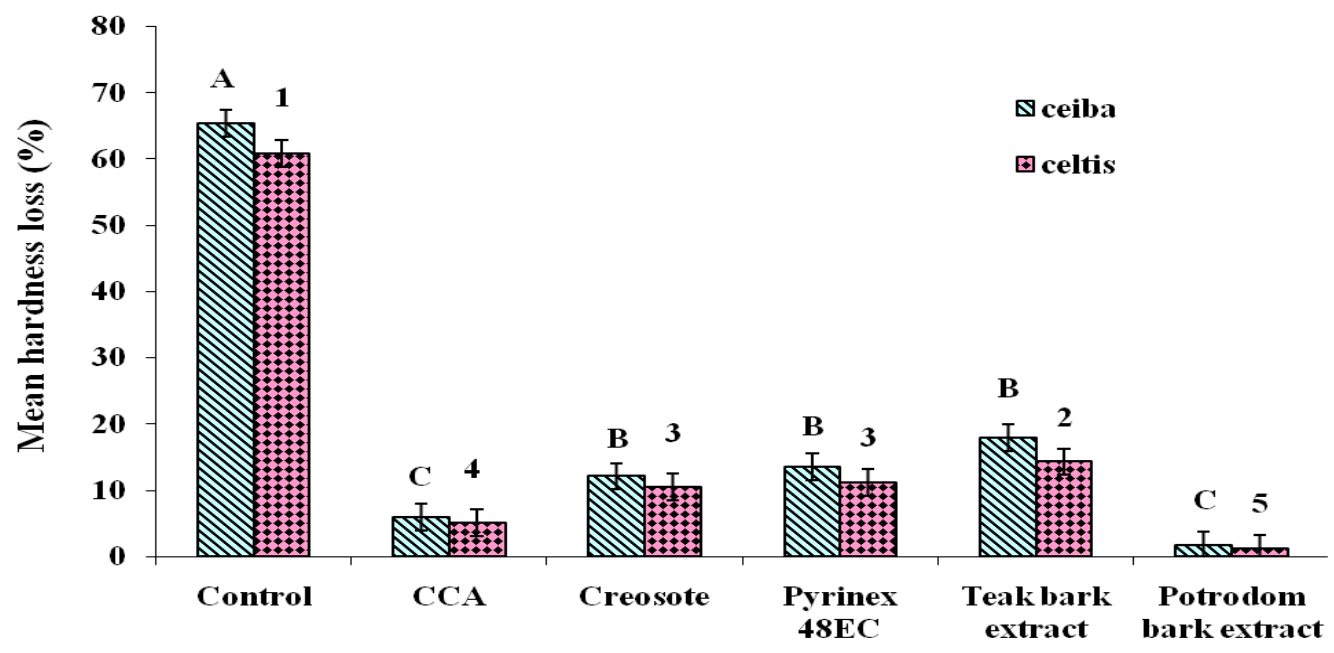

Ceiba and celtis untreated (control) and treated stakes

Bars $=$ standard errors. Bars with same letters or figures are not significantly different $(p<0.05)$

Fig. 3: Hardness losses for untreated (control) and treated $C$. pentandra (ceiba) and $C$. milbraedii (celtis) stakes

Journal of Science and Technology ㄷN KNST April 2010 
Table 4a: ANOVA for percentage mass loss for treated and untreated ceiba and celtis stakes

\begin{tabular}{lccccc}
\hline Source & Degree of Freedom & Sum of Squares & Mean Square & F-Value* & Pr $>$ F \\
\hline Error & 14 & 35184.74 & 1851.83 & 12.60 & $<0.0001$ \\
Corrected & 135 & 23520.66 & 147.00 & & \\
Total & 149 & 58705.41 & & & \\
\hline
\end{tabular}

*Significant difference at $p<0.05$.

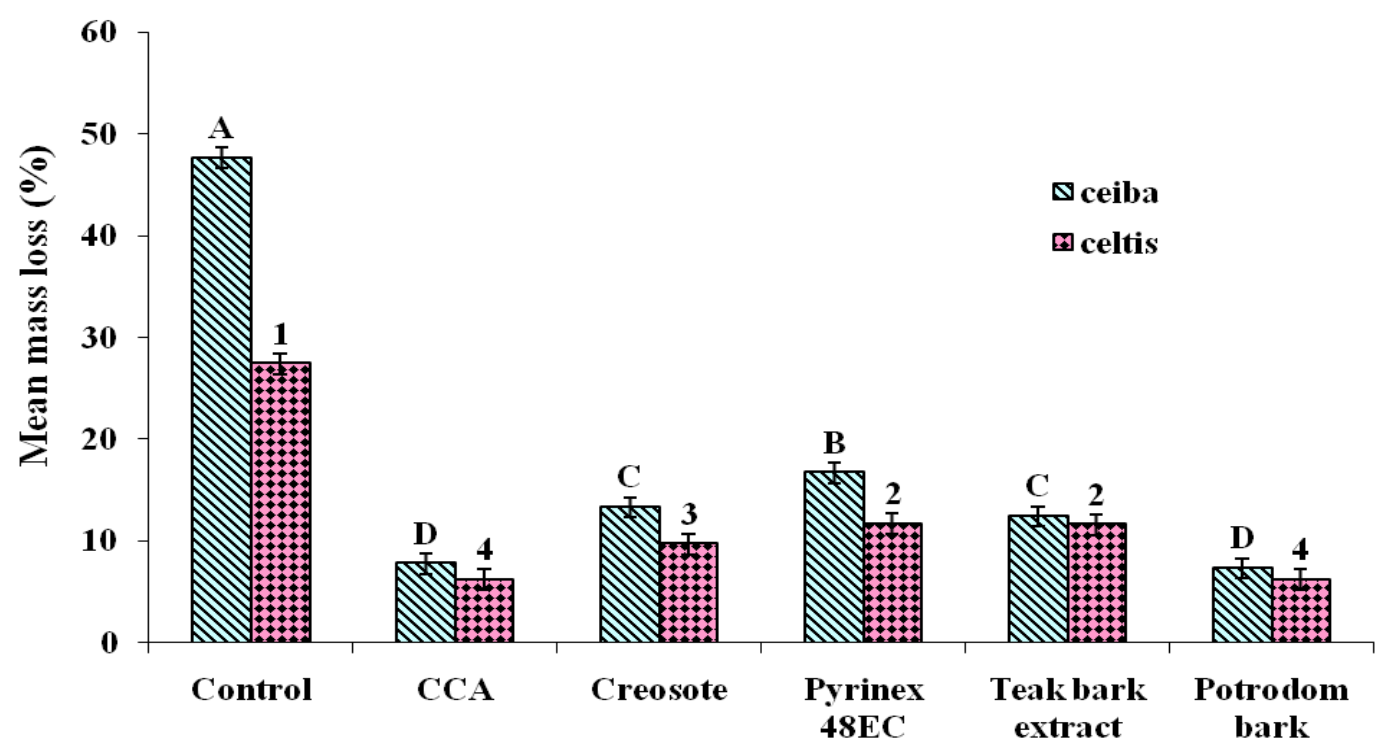

Ceiba and celtis untreated (control) and treated stakes

Bars $=$ standard errors. Bars with same letters or figures are not significantly different $(p<0.05)$

Fig. 4: Mass losses for untreated (control) and treated $C$. pentandra (ceiba) and $C$. milbraedii (celtis) stakes.

DISCUSSION

Retention of inorganic preservatives and organic extracts in stakes

Preservative absorption and retention in wood depend on several factors including its properties (e.g. anatomy, strength and mc), preservative viscosity, treatment plant and schedule. For ceiba stakes to record higher preservative retentions than those of celtis could be attributed to variations in their physical and anatomical characteristics. Wood of ceiba is lighter $\left(300 \mathrm{~kg} / \mathrm{m}^{3}\right.$ at $\left.12-15 \% \mathrm{mc}\right)$, softer, lower in strength and coarser (Bolza and Keating, 1972; Farmer, 1972) than celtis, which is about $2 \frac{1}{2}$ times heavier (i.e. $750 \mathrm{~kg} / \mathrm{m}^{2}$ at $12-15 \% \mathrm{mc}$ ), stronger (i.e. medium) with more interlocking grains (Anon., 1995). Thus, the lighter ceiba stakes could imbibe and retain more preservatives than those of celtis. The overall lower oilbased creosote retention in the stakes of the two timbers than the water-borne types is due to its highest viscosity and lowest reactivity (Wegner et al., 1989). According to them, lower viscous and active types reduce their bonding to the cell 
lumina and walls. Water-based preservatives are highly reactive in wood, while preservatives of higher viscosity normally inhibit easy flow of their chemicals into wood. Pyrinex 48EC, $E$ suaveolens and teak bark extracts are all waterborne and could be absorbed and retained most in the stakes. The highly reactive, less viscous, water-borne CCA was equally well retained. The water-borne characteristics of the plant extracts and their inorganic counterparts made penetration in the wood cells easier and bonding to the lumina and walls better than the more viscous creosote.

\section{Durability assessment of stakes after field exposure \\ Visual durability rating}

Visual durability rating is one of the means employed to assess the extent of external damage to stakes on exposure to wood-damaging agents particularly in the field (Anon. [EN 252], 1989). Ceiba is less durable than celtis (Fortin and Poliquin, 1976; Anon., 1995). Being more vulnerable to attack, it is not startling that ceiba controls should record higher ratings than their treated counterparts. Findlay (1985) reported that woods that are more susceptible to attack by decaying agents would show more decay symptoms when exposed to biodeterioration. FAO (1991) noted that such woods could offer resistance against damage by bio-degraders such as termites, marine borers and decay-fungi only when they are efficiently preservative-treated. Stakes treated with organic extracts of E. suaveolens and T. grandis barks had the least visual durability ratings comparable to those impregnated with CCA, an inorganic preservative. This indicates that these pure extracts have potent chemicals, which contributed to impart resistance to wood against bio-degraders far greater than the effect of creosote and Pyrinex 48EC (two of the three inorganic preservatives employed for this study). Moreover, for celtis-treated mini-stakes to have greater resistance against biodegradation than those of ceiba stems from the fact that the former are by far more naturally durable. Thus, although the conventional pre- servatives and organic extracts could impart durability to the stakes, other properties of their cells would also contribute to influence their resistance against bio-deterioration. However, the fact that the differences in the visual durability ratings for the stakes treated with CCA, teak and E. suaveolens bark extracts are not significant $(\mathrm{p}<0.05)$ testifies to the promising nature of organic extracts as potential wood preservative alternatives for inorganic types.

\section{Hardness loss}

Once more, the untreated ceiba stakes recorded greater hardness losses than those of celtis. The latter has been reported by Anon. (1995) to be stronger, heavier, harder and more durable than ceiba. Bultman et al. (1989) confirmed that an inverse relationship exists between wood hardness and damage by bio-degraders such that the harder the wood, the higher its resistance against bio-deterioration. E. suaveolens-treated stakes could maintain their hardness properties most followed by those treated with CCA. Chemicals of these water-borne preservatives could give much protection to stakes of the non -durable timbers and hardly predisposed them to attack by bio-degrading agents; they were the least soft after field exposure. Apart from CCA, E. suaveolens extract-treated stakes were harder and more durable than their counterparts treated with the other conventional preservatives. Negi (2004) observed hardness as a contributory feature for wooden flooring at skating rinks, indoor stadia and dancing halls, tool handles and railway sleepers, as hard woods are sturdy, able to retain their shapes and have shock-resisting ability. Therefore, since wood hardness contributes to reduce its damage, it is worth-noting that the organic preservatives (especially E. suaveolens extracts) would be as effective as the inorganic types (e.g. CCA) in preserving woods for end-uses which require greater strength.

\section{Mass loss}

Mass loss determines the amount of wood materials that has been removed by bio-degraders on exposure to field conditions (Anon., 1989) 
or in the laboratory (Anon., 1994). As usual, the untreated ceiba and celtis control stakes were severely attacked and lost the greater masses than the treated. The inherent extractives and other cell properties of the untreated stakes could not offer them adequate resistance against bio-deterioration. According to Fortin and Poliquin (1976), the two timbers are naturally very susceptible to wood-damaging organisms in the ground. More wood materials in the controls were removed than those taken from those treated, especially with $E$. suaveolens extract and CCA. Mini-stakes treated with $T$. grandis extracts also had their durability improved (Baidoo et al., 2009). However, the efficacy of $T$. grandis has been below that of $E$. suaveolens. The performance of $T$. grandis extract-treated stakes in the field resembles those treated with several of the inorganic preservatives (i.e. Pyrinex 48EC and creosote). Thus, in considering mass loss as a durability parameter, these natural preservatives have once more proved as efficient as the conventional or inorganic preservatives. It is important to stress that the active components within the extracts (especially for E. suaveolens) offered adequate protection to the stakes and contributed to make them resist bio-degradation. This study has shown that trends in mass losses for the stakes of each timber are consistent with those of their visual durability ratings and hardness losses. These durability assessment parameters with different classes of preservatives have revealed that organic preservatives (e.g. plant extracts) could be as efficacious against bio-deterioration as the inorganic types. For instance, in a laboratory soil block test, Onuorah (1999) treated $C$. pentandra stakes with Milicia excelsa (Welw.) C. C. Berg and E. suaveolens heartwood extracts, exposed them to 14-week microbial attack and found those with dosages of 48.06 and $96.11 \mathrm{~kg} / \mathrm{m}^{3}$ resistant to fungal attack. From the foregoing, indications are that the use of natural chemicals contained in all parts of very durable plant species (as in the heartwood extractives) as a substitute for the conventional types in protecting wood in service is very prospective and requires more investigation. Though they could be potent, the active ingredients in extracts from all organic sources including durable timbers (e.g. $E$. suaveolens and $T$. grandis barks) need efficient analysis to establish their safety and ecofriendliness before utilization.

\section{CONCLUSION}

Ceiba stakes retained more preservatives than those of celtis. Preservation uptake and retention were lowest for the more viscous, oil-based creosote than the water-borne types (i.e. CCA, Pyrinex 48EC and E suaveolens and T. grandis bark extracts).

Treated stakes with extracts from the two timbers barely had stains or other forms of discolorations on their surfaces. Thus, they have the ability to control stain-fungi and moulds.

For all the durability parameters assessed, $E$. suaveolens bark extract has very successfully proved as efficacious as the noxious CCA in preserving wood against bio-deterioration. Extracts from $T$. grandis bark also performed as effective as creosote and Pyrinex 48EC. Thus, organic preservatives from the natural plant sources (i.e. E. suaveolens and T. grandis) can be efficient alternatives for the conventional types presently studied.

\section{ACKNOWLEDGEMENT}

We express our profound gratitude to Andrew Bayuko and Johnson K. Addai of the Department of Wood Science \& Technology Workshop and the other Departmental staff, personnel of the Faculty of Renewable Natural Resources (FRNR) Experimental Farm, KNUST and Ms Agnes Ankomah (Biometrician, Crop Research Inst., CSIR, Kumasi). In diverse ways, they have contributed to produce this work!!!

\section{REFERENCES}

Anon. (1989). [BS EN 252]. Field Test Method for Determining the Relative Protective effectiveness of a Wood Preservative in Ground Contact; BS 7282: 1990. 
Anon. (1994). [BS EN 350-1]. Durability of Wood and Wood-based Products - Natural Durability of Solid Wood. Part 1. Guide to the Principles of Testing and Classification of the Natural Durability of Wood.

Anon. (1995). The Tropical Timbers of Ghana. Timber Export Development Board [TEDB] Takoradi, Ghana; London, UK. 42pp.

Anon. (2005). Treated Wood. Florida Wood Council. 4pp.

Anon. (2009). Wood Preservation Canada (http://www.woodpreservation.ca).

Baidoo, A. H., Asamoah, A. and AntwiBoasiako, C. (2009). Efficacy of Teak Bark Water Extracts against that of Conventional Preservatives. Agricultural Innovations for Sustainable Development: Volume 1 Issue 1. Published by the African Technology Policy Studies Network, Nairobi Kenya. Pp. 59-64.

Bolza, E. and Keating, W. G. (1972). African Timbers - The properties, Uses and Characteristics of 700 species. CSIRO Div. of Build. Res. Melbourne, Australia. http:// www2.fpl.fs.fed.us/publications/chud africa.pdf

Brunner, M. Y. and Grüsser, F. (2006). Investigations on Lesser-Used Timber Species for the Construction of light Bridges in Ghana. $1^{\text {st }}$ Interim Report 200506, DEZA/SNSF. Biel, Switzerland.

Bultman, J. D., Beal, R. H. and Ampong, F. F. K. (1978). The Natural Resistance of Ghanaian Woods to Coptotermis formosanus Shiraki. In A Force-Feeding Situation. Naval Research Laboratory, Washington D.C.

Ejechi, B. O. (2004). Effect of rude mansonia (Mansonia altisima) timber extracts on biodeterioration of obeche (Triplochiton scleroxylon) timber by three wood-rotting fungi. World Journal of Microbiology \& Technology, Springer, Netherlands. 631633pp.
Al-Jeboury F. S., H. D. Locksley 1971. Xanthones in the Heartwood of Calophyllum inophyllum: A geographical survey Phytochemistry, Volume 10, Issue 3, 603$606 \mathrm{pp}$.

Farmer, R. H. [ed.] (1972). Handbook of Hardwoods. H. M. Stationery Office, London. http://www2.fpl.fs.fed.us/publications/ chud_africa.pdf

Findlay, W. P. K. (1985). Preservation of Timber in the Tropics. Marttinus and Nighoji / Dr. Junk Publishers. Dordrecht. 53pp.

Food and Agricultural Organization (FAO). 1991. Wood Preservation Manual. FAO paper No. 76.

Fortin, Y. and Poliquin, J. (1976). Natural Durability and Preservation of One Hundred Tropical African Woods. International Development Research Centre, Ottawa, Canada. Pp. 1-129.

Goktas, O., Mammadov, R., Duru, M.E., Ozen, E., Colak, M.A., Yilmaz, F., (2007). Introduction and Evaluation of the Wood Preservative Potentials of the Poisonous Sternbergia candidum Extracts. African Journal of Biotechnology 6, 982-986.

Green, D. W., Winandy, J. E. and D. Kretschmann, E. (1999). Mechanical Properties of Wood In:Forest Products Laboratory. 1999. Wood handbook-Wood as an engineering material. Gen. Tech. Rep. FPL -GTR-113. Madison, WI: U.S. Department of Agriculture, Forest Service, Forest Products Laboratory. 463 p.

http://www.uapca/product/document/pyrinex : Pyrinex 48EC. (Sourced: 26-03-09).

Iinuma, M.; Tosa, H.; Tanaka, T.; Yonemori, S. (1994). Two xanthones from root bark of Calophyllum inophyllum. Phytochemistry, Volume 35, Issue 2, 527-532pp.

Negi, S. S. (2004). Wood Science and Technology. Applied Forestry Series No. 2. Prashant Gahlot at Valley Offset Printers \& Publishers, International Book Distributors, Dehra Dun, India. 249pp. 
Onuorah, E. O. (1999). The Wood Preservation Potentials of Heartwood Extracts of Milicia excelsa, Erythrophleum suaveolens. Department of Forestry, Wildlife and Range Management. University of Agriculture, Makurdi, Nigeria.

Richardson, B. A. (1978). Wood Preservation.The Construction Press Ltd. Lancaster, England. 238pp.

Wegner, T. H., Baker, A. J., Bendtsen, B. A., Highley, T. L., and Howard, J. L. (eds.) (1989). Wood. In: Mark-BikalesOverberger-Menges Encyclopedia of Polymer Science and Engineering. Vol. 17. $2^{\text {nd }}$ ed. John Wiley and Sons, New York.
Williams, R. S. and Feist, W. C. (1999). Water Repellents and Water-Repellent Preservatives for Wood. United States Department of Agriculture, Forest Service, Forest Products Laboratory, General Technical Report FPL-GTR-109. Madison, WI: U.S. 12 p. 